\title{
SOEP
}

SOEPpapers

SOEPpapers
on Multidisciplinary Panel Data Research

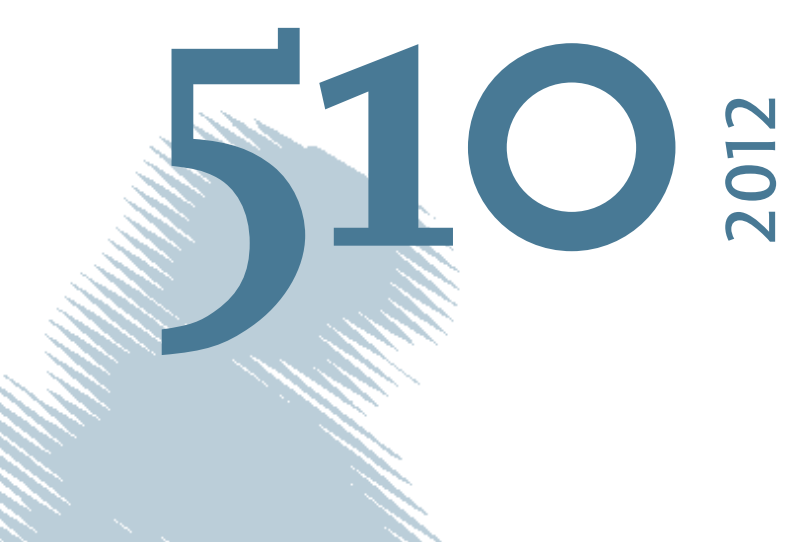

Wh

n

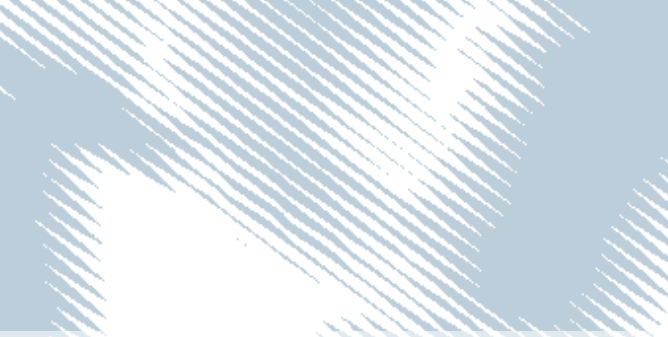

\section{Intergenerational Earnings Mobility and Preferences for Redistribution}




\section{SOEPpapers on Multidisciplinary Panel Data Research}

at DIW Berlin

This series presents research findings based either directly on data from the German SocioEconomic Panel Study (SOEP) or using SOEP data as part of an internationally comparable data set (e.g. CNEF, ECHP, LIS, LWS, CHER/PACO). SOEP is a truly multidisciplinary household panel study covering a wide range of social and behavioral sciences: economics, sociology, psychology, survey methodology, econometrics and applied statistics, educational science, political science, public health, behavioral genetics, demography, geography, and sport science.

The decision to publish a submission in SOEPpapers is made by a board of editors chosen by the DIW Berlin to represent the wide range of disciplines covered by SOEP. There is no external referee process and papers are either accepted or rejected without revision. Papers appear in this series as works in progress and may also appear elsewhere. They often represent preliminary studies and are circulated to encourage discussion. Citation of such a paper should account for its provisional character. A revised version may be requested from the author directly.

Any opinions expressed in this series are those of the author(s) and not those of DIW Berlin. Research disseminated by DIW Berlin may include views on public policy issues, but the institute itself takes no institutional policy positions.

The SOEPpapers are available at

http://www.diw.de/soeppapers

\section{Editors:}

Jürgen Schupp (Sociology, Vice Dean DIW Graduate Center)

Gert G. Wagner (Social Sciences)

Conchita D'Ambrosio (Public Economics)

Denis Gerstorf (Psychology, DIW Research Director)

Elke Holst (Gender Studies, DIW Research Director)

Frauke Kreuter (Survey Methodology, DIW Research Professor)

Martin Kroh (Political Science and Survey Methodology)

Frieder R. Lang (Psychology, DIW Research Professor)

Henning Lohmann (Sociology, DIW Research Professor)

Jörg-Peter Schräpler (Survey Methodology, DIW Research Professor)

Thomas Siedler (Empirical Economics)

C. Katharina Spieß (Empirical Economics and Educational Science)

ISSN: 1864-6689 (online)

German Socio-Economic Panel Study (SOEP)

DIW Berlin

Mohrenstrasse 58

10117 Berlin, Germany

Contact: Uta Rahmann | soeppapers@diw.de 


\title{
Intergenerational Earnings Mobility and Preferences for Redistribution
}

\author{
Thomas Siedler* \\ University of Hamburg, \\ DIW Berlin, University of \\ Essex and IZA Bonn
}

\author{
Bettina Sonnenberg ${ }^{+}$ \\ Max Planck Institut für \\ Bildungsforschung and \\ DIW Berlin
}

\begin{abstract}
This paper analyzes the extent to which intergenerational upward and downward mobility in earnings are related to individuals' preferences for redistribution. A novel survey question from the German Socio-Economic Panel Study - whether the taxes paid by unskilled workers are too high, adequate or too low-are used to elicit attitudes toward redistribution. Intergenerational mobility with regard to long-term earnings is measured using a rich panel data spanning an observation window of 22 years. The results reveal that intergenerational mobility is significantly related to preferences for redistribution. The empirical results yield strong and robust support for Piketty's (1995) rational-learning theory: individuals who experience upward (downward) intergenerational mobility are less (more) likely to favor redistribution taxation policies.
\end{abstract}

This version: October 2012

JEL codes: J62; $\mathrm{H} 23$;

Keywords: Preferences for redistribution, intergenerational mobility, long-run earnings, panel data

* Corresponding author: Thomas Siedler, University of Hamburg, Von-Melle-Park 5, 20146 Hamburg. Tel.: +49 4042838 9460; Fax: +49 4042838 9461. E-mail: thomas.siedler@ wiso.uni-hamburg.de.

+ Bettina Sonnenberg, DIW Berlin, Mohrenstr. 58, 10117 Berlin. Tel.: +49 30 89789-461; Fax +49 30 89789-109 E-mail: bsonnenberg@diw.de. 


\section{Introduction}

Individual preferences for redistribution play an important role in political and economic theories. A recent theoretical model of redistributive politics assigns a key role to social background and economic mobility: individuals who have experienced upward mobility are more likely to believe that effort is rewarded in society and are less likely to support redistribution policies. In contrast, individuals who have experienced downward mobility are less likely to think that effort is rewarded and are more likely to prefer redistribution taxation policies (Piketty, 1995).

This paper builds on Piketty's rational-learning theory and analyzes the empirical relationship between economic mobility and preferences for redistribution. In particular, it examines whether and to what extent intergenerational mobility with regard to long-term earnings is related to individuals' preferences for redistribution by using a very rich longitudinal data set, combining information from the first twenty-two annual interview waves (1984-2006) from the German Socio-Economic Panel Study (SOEP). A novel question on whether the taxes paid by unskilled workers are too high, adequate or too low are used to elicit attitudes toward redistribution. The empirical results provide evidence consistent with Piketty's (1995) theory that there is a significant and robust relationship between economic mobility and individual preferences for redistribution. The results of the present study can be summarized as follows. First, fathers' and own average long-term earnings are significantly correlated to adult sons' preferences for redistribution. Using longterm earnings averaged over multiple years-rather than using single-year measures of earnings - assign a more important role to the relationship between economic status and support for redistribution than previously reported in the literature using cross-sectional data. ${ }^{1}$ Second, the results of this analysis point to considerable differences in preferences for redistributive taxation according to the economic trajectories experienced by individuals relative to those of their fathers. Among adult sons who grew up with fathers whose longterm earnings were below the median of the income distribution, 63 percent of those who experienced intergenerational upward mobility favor distribution taxation, compared to 74 percent among adult sons who did not experience intergenerational upward mobility.

\footnotetext{
${ }^{1}$ The majority of studies in the empirical literature on preferences for redistribution use single-year measures of income or earnings. However, single-year observations are poor measures for life-time earnings due to transitory fluctuations in earnings or mistakes in reporting income or earnings. For example, averaging earnings over multiple years to reduce measurement error and attenuation bias has been shown to be an important method in several intergenerational mobility studies (see, for example, Solon, 1992; Zimmerman, 1992; Dearden et al., 1997).
} 
Similarly, intergenerational downward mobility is also closely linked to individuals' preferences for redistribution. Third, the relationships between upward and downward intergenerational mobility are very robust to controlling for other influences which were found to be important in previous work on preferences for redistribution such as altruism (Alesina and La Ferrara, 2005), optimism, self-determination, and beliefs in a just world (Fong, 2001; Alesina et al., 2001; Corneo and Gründer, 2002; Bénabou and Tirole, 2006), reciprocity (Fong et al., 2005), and risk aversion (Bénabou and Ok, 2001). Moreover, the estimates are robust to using an alternative measure of economic status (fathers' and sons' unemployment experience) and eliciting individuals' preferences for redistribution through questions on the extent to which the government should be responsible for helping the unemployed (Alesina and Fuchs-Schündeln, 2007). The empirical results are unlikely to suffer from lifecycle bias as they are robust to variation in the age of adult sons over which average earnings are measured (Grawe, 2006). Moreover, the estimates are found to be robust to controlling for individuals' wealth (Pfeffer, 2011), expectations for future mobility (Alesina and La Ferrara, 2005; Bénabou and Ok, 2001), regional characteristics, such as the local unemployment rate and the proportion of foreigners (Luttmer 2001; Dahlberg et al. 2012), and the intergenerational transmission in preferences for redistribution between fathers and sons. Taken together, the results presented in this paper point to an important relationship between intergenerational mobility in long-term earnings and individual preferences for political redistribution. The empirical results are in line with Piketty's (1995) theory of redistributive politics which assigns a key role to economic mobility and social origin on redistribution policies.

The rest of the paper is structured as follows: The following section discusses the related literature. Section 3 briefly discusses the main implications of Piketty's model in the present intergenerational mobility context. Section 4 describes the data, sample selection, and summary statistics. Sections 5 and 6 present the empirical results, and section 7 discusses various sensitivity analyses. The final section concludes.

\section{Related Literature}

Our study is connected with two previously unrelated literatures. The first literature studies how individual and regional characteristics are correlated to preferences for redistribution (Alesina and La Ferrara, 2001; Fong, 2001; Corneo and Grüner, 2002; Ravallion and Lokshin, 2000; Rainer and Siedler, 2008; Senik et al., 2009; Stichnoth, 2010; Alesina and Giuliano, 2010) and a number of papers attempt to estimate causal effects on individuals' 
support for redistribution (Alesina and Fuchs-Schündeln, 2007; Di Tella et al. 2007; Krashinsky, 2007; Giuliano and Spilimbergo, 2009; Dahlberg et al., 2012). Alesina and Fuchs-Schündeln (2007) examine the extent to which individuals' preferences for redistribution are shaped by the political regime under which they lived. The authors find that East Germans who experienced living under a socialist system are more in favor of redistribution than West Germans who grew up in a free-market economy. This is in line with previous work by Corneo and Grüner (2002) which finds that individuals in former socialist countries are more in favor of redistribution than those in Western countries. Di Tella et al. (2007) study how an exogenous allocation of property rights to land squatters in Buenos Aires impacts on their beliefs. The authors find that those who were randomly assigned legal land titles developed more materialistic and individualistic believes compared to squatters without property rights. Krashinsky (2007) uses a data set of twins containing information on twins' own education and earnings and twin's perception regarding his or her siblings' education and earnings to evaluate Piketty's (1995) theory of within-family learning. Consistent with this theory, the author finds large positive correlations in political beliefs among siblings. In addition, ordered-response models controlling for family-specific fixedeffects also suggest that within-family learning is important for individuals' political beliefs. Giuliano and Spilimbergo (2009) report that individuals growing up during recessions tend to favor more government distribution and are more likely to believe that success in life depends more on luck than effort. The study by Brunner et al. (2011) exploits exogenous shocks to labor demand to estimate the effects of economic conditions on redistributive and nonredistributive policies at the aggregate level. The authors find that positive economic shocks lead to a drop in support for redistribution policies. Finally, the recent study by Dahlberg et al. (2012) examines the effect of ethnic diversity on individuals' preferences for redistribution. Exploiting exogenous variation in immigrant shares in Sweden as a result of a nationwide refugee placement program, the authors find that increased immigration has a negative impact on the support for redistribution among natives. The effect is found to be particularly strong among high-income earners. For recent literature reviews on preferences for redistribution see Alesina and Giuliano (2010) and Stichnoth et al. (forthcoming). ${ }^{2}$

\footnotetext{
${ }^{2}$ There is also a growing experimental literature studying redistribution preferences and voting behavior in the laboratory. We do not review this literature here, but interested readers might consult, for example, Durante and Putterman (2007), Krawczyk (2010) and Klor and Shayo (2010).
} 
The second related literature focuses on estimating the degree of intergenerational mobility. ${ }^{3}$ The degree of intergenerational mobility is commonly interpreted as a measure of the extent of equality of opportunity in a society. Recent international comparisons indicate that the extent of intergenerational earnings mobility varies dramatically across industrialized countries: The US and the UK are found to be the least mobile countries, the Nordic countries and Canada are characterized by the highest degree of intergenerational mobility, and Germany and France rank in the middle (see, for example, Couch and Dunn, 1997; Björklund and Jäntti, 1997; Solon, 2002; Jäntti et al., 2006). Despite a comprehensive literature on the extent of intergenerational mobility within and across countries, economists have paid relatively little attention to examining the potential consequences of upward and downward intergenerational mobility for individuals' preferences and beliefs. The present study attempts to fill this gap by focusing on whether differences in intergenerational mobility are correlated to differences in individuals' perceptions of taxation policies.

Previous empirical work analyzing preferences for redistribution that touched upon an intergenerational aspect has been limited to cross-sectional data with retrospective information. For example, Alesina and La Ferrara (2005) use information on whether individuals' job prestige is higher than those of their fathers' and the difference between respondents' own and their fathers' years of education as proxies aimed at capturing intergenerational mobility. In their study, job prestige and years of education of both generations were reported by adult children. Similarly, Corneo and Grüner (2002) include a dummy variable 'Better off than father' as a proxy for intergenerational upward mobility in their empirical analysis. While the focus of these two studies was not on the relationship between intergenerational mobility and preferences for redistribution per se, together, they provide some first evidence that intergenerational mobility might be correlated to people's attitudes towards redistribution. However, measuring parents' socioeconomic characteristics on the basis of children's recollections might result in severe errors-in-variables bias due to response errors. In contrast, using self-reported long-term earnings for both children and parents on the basis of contemporaneous information from household panel data is likely to

\footnotetext{
${ }^{3}$ See, for example, the studies by Björklund and Jännti (1997), Dearden et al. (1997), Bowles and Gintis (2002), Nicoletti and Ermisch (2007) and the various chapters in the volume edited by Corak (2004). For recent surveys of the intergenerational mobility literature in earnings and education see Solon (2002), Black and Devereux (2011), Holmlund et al (2011).
} 
result in a more accurate measurement of intergenerational trajectories (Solon, 1992; Zimmerman, 1992). ${ }^{4}$

\section{Piketty's Intra-Family Learning Model and Intergenerational Mobility}

Piketty's (1995) theoretical model assigns great significance to family background and economic mobility in terms of their impact on individuals' preferences for redistribution. The model assumes that individuals start with an initial value of preferences for redistribution depending on their parents' political beliefs and their social origin. Over the years, adult children update their political views on the basis of the relative importance of effort and luck for economic outcomes that they observe in their family. The present paper provides an analysis of the importance of family origin and economic mobility in the family on attitudes toward redistribution, by focusing on son-father economic relationships. The analysis specifically examines the extent to which intergenerational mobility results in adult sons adjusting their attitudes towards redistribution. For example, if children experience that effort (rather than social origin) is rewarded in life inasmuch as they experienced upward mobility in earnings compared to their fathers, they might be likely to adjust their political beliefs with regards to the impact of effort versus social origin on 'success' in life. Thus, adult children who have experienced intergenerational upward mobility might be less likely to be in favor of redistribution policies compared to those with no or lower levels of intergenerational earnings mobility. In contrast, adult children who have experienced intergenerational downward mobility might be more likely to think that luck, rather than effort, determines individuals' success in life and, hence, are more likely to support redistribution from the poor to the rich.

\section{Data and Sample Selection}

The present study exploits data from the German Socio-Economic Panel Study (SOEP). The SOEP is a large nationally representative household panel, the first wave of which was conducted in 1984. From 1990 on, the SOEP included new households and individuals in the territory of the former German Democratic Republic. The core questionnaire elicits information about labor market behavior, income, education, household composition and marital status at each annual interview. For more detailed information about the SOEP see Wagner et al. (2007) and references therein.

\footnotetext{
${ }^{4}$ The contemporaneous collection of information is crucial for the reliability of measurement because respondents do not have to recall detailed pieces of information. For example, there is ample evidence in the literature report that people do not recall past events flawlessly and the longer the recall period, the more likely memories will contain systematic errors (Peters, 1988; Rubin, 1996).
} 
A key feature of the survey for intergenerational research is that children of original household members become adult panel respondents in their own right in the year they turn 17 and are then followed over time. These children have lived with a parent who was (and may well remain) a panel member too. Thus, it is possible to match adult children to their parents and to observe self-reported earnings of both generations over time. To date, the SOEP makes it possible to relate adult children's earnings to their parents' earnings drawing on more than twenty years of retrospective data. Occasionally, the SOEP also supplements the core questionnaire with special modules on preferences for redistribution. In 2005, the SOEP asked respondents detailed questions about their tastes for redistribution.

\subsection{Preferences for Redistribution}

To capture respondents' preferences for redistribution the study makes use of a novel question in the SOEP 2005 questionnaire: "In Germany, everyone has to pay taxes in relation to his or her income. Those who earn more have to pay higher taxes (also known as "progressive taxes"). What do you think: Is the amount of tax paid by an unskilled worker in Germany too high compared to other groups, too low, or exactly appropriate?" Figure 1 shows the distribution of responses to this survey question. It is apparent that, on average, individuals display a marked preference for redistribution such that they think that tax paid by those at the lower end of the income distribution are too high. For example, 62 percent of adult sons answer that the amount of tax paid by an unskilled worker is too high and 36 percent respond that the taxes paid are appropriate. Figure 1 also shows that there are only very few respondents who answer that the taxes for unskilled workers are too low. We therefore collapse the answer categories "too little" and "adequate" into one category and use this dichotomous variable as our dependent variable. In the light of these descriptive statistics, it is important to keep in mind that Germany's progressive taxation system stipulates a maximum income tax rate of 40 percent and a minimum of tax rate of 15 percent. As a result, in Germany in 2010, the average personal tax rates-defined as the sum of income tax and employee social security contributions as a percentage of gross wage earnings-is 39 percent, compared to 23 percent in the US and 25.5 percent in the UK (OECD, 2011: 18). 


\subsection{Adult Children's and Fathers' Average Earnings}

The present study exploits the rich panel structure of the SOEP and uses the first 22 waves, observing earnings over the period 1983-2005. ${ }^{5}$ The SOEP makes it possible to observe both adult children and their fathers at economically active ages. Fathers' earnings are averaged across all the years between 1983 and 2004 in which the father reports positive earnings and is aged between 18 and 65. Earnings are averaged over as many years as possible to minimize measurement error and to obtain more accurate intergenerational estimates (Solon, 1992; Zimmerman, 1992; Dearden et al. 1997). The sample is restricted to those adult children for whom positive fathers' annual labor earnings are observed for at least three years. In fact, on average, fathers' earnings are observed for more than 13 years. The main sample comprises adult children aged 20 and above in the survey year 2005, for whom average earnings are measured over the years 2000-2005. On average, children's earnings are observed for nearly 4 years. As a result, the sample includes 837 father-son pairs. One potential problem with adult children's earnings measured at relatively young ages is that they might not adequately capture life-time earnings (Grawe, 2006). The study returns to this issue and presents a detailed sensitivity analysis in Section 7.

One common method of describing the degree of intergenerational mobility is through transition matrices which makes it possible to study movements between quartiles over a generation. In this approach, the population of father-son pairs is divided into equal sized groups which are ranked in order of their earnings. In a completely mobile society, adult children's earnings are independent of their parents' earnings. In this case, the proportion of child-parent pairs in each cell of an intergenerational quartile transition matrix would be 0.25. In the case of complete intergenerational immobility, all child-parent pairs stay on the leading diagonal of the matrix such that all cells on the diagonal contain a 1 and the off-diagonals a 0 . One advantage of this approach is that it provides information about the nature and the extent of mobility between generations. Table 1 displays the intergenerational transition matrix in long-term earnings between fathers and adult children in our sample. The table shows considerable intergenerational mobility. For example, around 28 percent of sons born to fathers with earnings in the bottom quartile experienced upward mobility to the second quartile. In line with previous studies, persistence in intergenerational earnings mobility is highest in the tails of the distribution, with sons whose fathers' earnings in the bottom and top of the earnings distribution appear to be less likely to experience intergenerational mobility

\footnotetext{
${ }^{5}$ Note that the information on the annual earnings for the year 2005 partly come from the questionnaire in 2006.
} 
than sons born to fathers with earnings in the second and third quartiles (Dearden et al. 1997). ${ }^{6}$

The transition matrix approach also provides a first descriptive look at the relationship between intergenerational earnings mobility and preferences for redistribution. Panel $\mathrm{A}$ in Table 2 reports the proportion of individuals who think that tax paid by unskilled workers is too high, separately for each cell of the intergenerational transition matrix. In line with the descriptive evidence in Piketty (1995), the table demonstrates that individuals who have experienced upward or downward mobility display an intermediate position in their attitudes towards redistribution compared to those who did not experience intergenerational mobility. For example, 69 percent of sons who were born to fathers in the bottom quartile and whose own earnings were in the third quartile respond that the tax paid by unskilled workers in Germany is too high. In contrast, 80 percent of sons who were also born to fathers with earnings in the bottom of the distribution but who did not experience upward mobility support redistribution policies. The $2 \times 2$ intergenerational mobility matrix in Table 2 , Panel B also indicates that individuals who have experienced upward or downward mobility display an intermediate position with respect to their preferences for redistribution.

\subsection{Additional Covariates}

To mitigate concerns that unobserved characteristics might drive the results, we control for a rich set of socioeconomic characteristics for both fathers and sons. In line with the previous literature on the determinants of preferences for redistribution, in the multivariate regressions, the study also controls for the individuals' age, marital status, household family size, education and occupation (e.g., Alesina and Giuliano, 2010; Alesina and Fuchs-Schündeln, 2007; Rainer and Siedler, 2008). This gives an estimate of correlations between long-term earnings and sons' preferences for redistribution that are not subject to the influence of education and occupational decisions. In some specifications, sons' and fathers' willingness to take risks (Bénabou and Ok, 2001), sense of reciprocity and beliefs about the importance of self-reliance versus luck (Fong, 2001), and their optimism towards the future are also controlled for. Moreover, in a third specification we also control for the intergenerational transmission in preferences for redistribution. The summary statistics of explanatory variables for adult sons and fathers are in Table 3. The average age of sons is 33 in 2005, and

\footnotetext{
${ }^{6}$ Note, however, that the degree of immobility at the bottom and top of the transition matrix might be exaggerated since these non-linear patterns might simply reflect that, by design, upward mobility is not possible
} 
fathers' mean age is 62. On average, adult sons have higher levels of education than their fathers, are more willing to take risks in financial matters, and believe to a greater extent that life course depends on one's own effort. Moreover, they are less likely to be of the opinion that what you achieve in life depends on luck, compared to their fathers. Similarly, sons display higher levels of altruism and are more optimistic towards the future than their fathers.

\section{Fathers' Earnings, Sons' Earnings and Preferences for Redistribution}

Piketty's model of intra-family learning demonstrates the importance of family background characteristics for individuals' preferences for redistribution. Building on this model, we start our empirical analysis by examining the correlations between fathers' lifetime earnings, adult children's own earnings and their preferences for redistribution. First, the study estimates baseline probit models with sons' and fathers' long-term earnings as key explanatory variables, together with other individual socioeconomic variables and family background characteristics. ${ }^{7}$ In particular, we control for sons' and fathers' age and age-squared to capture life-cycle effects, whether sons are from a Gastarbeiter (guest or migrant worker) family or from the former German Democratic Republic. Moreover, the control variables include sons' years of education, marital status, number of children in the household, number of adults in the household, and five dummy variables for sons' occupation. Previous studies point to the importance of these background variables for individuals' preferences for redistribution (Corneo and Grüner, 2002; Alesina and La Ferrara, 2005; Alesina and FuchsSchündeln, 2007).

There are two key areas of interest for this study in reporting marginal effects from simple probit estimates for our outcome measure 'Evaluation of tax paid by unskilled workers' in Table 4. The first area of interest is the relationship between long-term average earnings of both generations and sons' preferences for redistribution, conditional on the other family background variables. The second area of interest lies in the relative importance of own long-term earnings compared to fathers' long-term earnings. Piketty's intra-family learning model demonstrates the importance of family background characteristics and the perception of social mobility in the family, but there is very little empirical evidence in the

for those born at the top and downward mobility for those born at the bottom of the earnings distribution (Corak and Heisz, 2003).

${ }^{7}$ In unreported regressions, we also estimated ordered response models using the three answer categories 'low', 'adequate' and 'too high', as displayed in Figure 1. The results were in line with the estimates from the bivariate probit model and are available from the authors upon request. 
existing academic literature on the relationship between fathers' and adult children's longterm earnings and preferences for political redistribution.

The results in Table 4 reveal a strong and statistically significant relationship between fathers' earnings, sons' earnings and adult sons' preferences for redistribution. The estimates suggest that men with higher earnings are less inclined to state that taxes paid by unskilled workers are too high than those with lower earnings. The same is true for the relationship between fathers' long-term earnings and sons' preferences for redistribution. For example, the marginal effects in Table 4 suggest that a 1 percent increase in fathers' long-term earnings decreases sons' likelihood of expressing that taxes paid by unskilled workers are too high by 11 percentage points. Interestingly, the association is stronger for fathers' than for sons' earnings, but the hypothesis of equality of the marginal effects cannot be rejected at the 5 percent significance level. Consistent with the results in Alesina and Fuchs-Schündeln (2007) the estimates suggest that East Germans are more in favor of redistribution than West Germans, with a difference between both groups of 10 percentage points. These first crosssectional estimates suggest that both social origin (measured by fathers' long-term earnings) and the recent economic position (proxied by adult sons' average earnings) seem to be important for individuals' preferences for redistribution.

In order to allow for a greater flexibility in the strength of the association across both sons' and fathers' earnings distribution, the study next investigates in more detail non-linear relationships between combinations of fathers' and sons' positions in the respective earnings distribution. To measure the degree of intergenerational mobility, 16 mutually exclusive dummy variables that capture all possible positions in the father-child earnings distribution are generated as reported in Table 1 . The reference category is father-son pairs both with earnings in the bottom of the earnings distribution $\left(\mathrm{q}_{1,1}\right)$. The estimated probit equation has the form:

$$
P\left(p_{i, 2005}=1 \mid x\right)=\Phi\left(\beta_{o}+\sum_{k=2}^{4} \beta_{1, k} q_{1, k}+\sum_{k=1}^{4} \beta_{2, k} q_{2, k}+\sum_{k=1}^{4} \beta_{3, k} q_{3, k}+\sum_{k=1}^{4} \beta_{4, k} q_{4, k}+x_{i} \gamma\right) .
$$

The outcome variable $p_{i, 2005}$ equals one if adult son $i$ says that the taxes paid by an unskilled worker in Germany are too high, and zero otherwise. Moreover, $k$ indicates the corresponding column in the child-parent intergenerational transition matrix. For example, the estimated coefficient of $\beta_{1,2}$ on the dummy variable $q_{1,2}$ captures the differences in preferences for redistribution between sons whose earnings are in the $2^{\text {nd }}$ quartile of the income distribution 
with sons, whose earnings are in the bottom of the income distribution, conditional on having fathers in the bottom of the earnings distribution. $\Phi$ denotes the standard normal cumulative distribution function. All other explanatory variables are captured by the vector $x_{i}$ such that $x_{i} \gamma=\gamma_{1} x_{1}+\gamma_{2} x_{2}+\ldots+\gamma_{j} x_{j}$

Panel A in Table 5 presents the marginal effects for the 15 intergenerational transition dummy variables, and Panel B reports the marginal effects for dummy variables which only capture whether sons' and father's long-term earnings are below or above the median. Piketty's theory predicts that individuals who experience upward (downward) mobility are less (more) likely to favor redistribution taxation policies. This implies that the most relevant estimates in Table 5 are the ones that are highlighted in grey (with darker grey indicating a larger extent of intergenerational mobility). First, there will be a discussion of the estimates for sons who experience intergenerational downward mobility in earnings (i.e., the estimated marginal effects in column 1). The estimated marginal effect of -0.227 in Panel A, column 1, suggests that sons with earnings in the bottom of the distribution and with fathers who are 'top earners' have a 23 percentage points lower likelihood to answer that taxes paid by unskilled workers are too high than those who stayed poor (e.g., both sons' and fathers' earnings are in the bottom of the distribution). The point estimate is not only statistically significant at the 5 percent level, but also economically important as it corresponds to a decrease in preferences for redistribution of around 37 percent. The estimates in Panel A also suggest that those who have experienced intergenerational upward mobility are less likely to support redistribution policies. The marginal effect on the dummy variable $\mathrm{q}_{1,3}$ (fathers' earnings in the bottom; sons' earnings in the third quartile of the earnings distribution) suggests, for example, that sons who experienced upward mobility from the bottom to the third quartile have a 24 percentage points lower likelihood of thinking that unskilled workers pay too much tax compared to adult sons who have not experienced intergenerational upward mobility (both fathers' and sons' earnings are in the bottom of the distribution). The results also point to a significant relationship between long-term intergenerational upward mobility and preferences for redistribution. High earning sons at the top of the distribution who are born to fathers with earnings in the bottom quartile are significantly more likely to oppose redistribution policies with a marginal effect of -0.314 being statistically significant at the 1 percent level. Finally, the estimates in Table 5 point to a strong negative relationship between preferences for redistribution among the persistently rich. Sons in the top quartile with fathers whose earnings are also in the top or third quartile are significantly less likely to oppose taxing the poor. Overall, the estimates in Table 5 provide first empirical evidence based on 
rich longitudinal data of long-term earnings in support of Piketty's (1995) intra-family learning model.

\section{Other (Regarding) Preferences}

Previous studies found that those who believe that society offers equal opportunities to all and that effort—rather than external circumstances—is important for economic success in the future oppose redistribution policies (Piketty, 1995; Alesina and La Ferrara, 2005). Similarly, Fong (2003) argues that beliefs about the causes of wealth, poverty, and preferences for redistribution are shaped by the extent to which individuals think that outcomes in life are self-determined or exogenously determined. The author reports that individuals who indicate that they think bad luck causes poverty (exogenous determination) are more supportive of redistribution than those who think that effort alone determines poverty status (selfdetermination). The SOEP 2005 survey includes a novel battery of questions about individuals' social beliefs. The exact wording of the question is: "The following statement applies to different attitudes towards life and the future. To what degree do you personally agree with the following statements?" In the light of Fong (2003), the study uses the answers to the statements that are likely to capture beliefs about self-determination and exogenous determination: (1) "How my life goes depends on me" and (2) "What you achieve in life depends on luck". Answers to the first question are likely to capture the extent to which respondents believe in self-determination, and answers to the second question are likely to capture beliefs about exogenous determination of outcomes in life. The answers to these statements are given on a 7-point scale, with 1 indicating "disagree completely" and 7 "agree completely". Risk-averse individuals are likely to be more in favor of redistribution as they might consider redistribution to be a kind of insurance against potential future adverse shocks (Bénabou and Ok, 2001). The present study uses respondents' answers to the following question from the SOEP 2004 questionnaire: "People can behave differently in different situations. How would you rate your willingness to take risks in the following areas?" The financial matters area is selected. The answer to risk question is given on an 11-point scale. The values are rescaled such that 1 indicates "risk averse" and 11 "fully prepared to take risk". 8 Moreover, the study controls for individuals' altruism, reciprocity and optimism (Alesina and La Ferrara, 2005; Fong et al., 2005). As a proxy for altruism, a dummy variable

\footnotetext{
${ }^{8}$ Dohmen et al. (2011) validated this survey question in a complementary real-stakes lottery experiment. The authors find that answers to this survey measure were a good predictor of actual risk-taking behavior in the field experiment.
} 
is generated which equals one if respondent indicates that it is very important for them to be there for others, and zero otherwise. To capture reciprocity, the study uses the following question: "To what degree do the following statements apply to you personally?" The statement "if someone does me a favor, I am prepared to return it" is used. The answer can be given on a 7-point scale, with 1 indicating "does not apply to me at all" and 7 "applies to me perfectly". The variable optimism is a dummy variable that equals one if respondents say that they are "optimistic" or "more optimistic than pessimistic" about the future, and zero otherwise. Finally, preferences for redistribution might correlate strongly between parents and adult children. In a second specification, the intergenerational association in preferences for redistribution is, therefore, also controlled for.

Table 6 reports the estimates conditional on sons' and fathers' risk attitudes, reciprocity, optimism about the future and their beliefs about the extent of equality of opportunity in society. The table presents results from two different specifications. In the first specification, sons' and fathers' attitudes and preferences are controlled for. In the second model, a potential intergenerational transmission in preferences for redistribution is also controlled for. The results in Table 6 indicate that the inclusion of these additional controls does not significantly change the key results. In fact, the marginal effects in Table 6 point to a slightly more important role of the experience of earnings mobility for adult sons' preferences for redistribution. For example, the estimated marginal effects in row 3 (e.g., fathers' earnings in the bottom of the earnings distribution, sons' earnings in the top quartile) of -0.342 (specification 1) and -0.407 (specification 2) are comparable in magnitude to the corresponding marginal effect in Table 5 (-0.314). ${ }^{9}$ Similarly, the estimated marginal effects for sons who have experienced long-distance downward mobility (e.g., fathers' earnings in the top quartile; sons' earnings in the bottom quartile) indicated that they are more in favor of redistribution compared to those who 'stayed poor'. Turning to the marginal effects of the additional preferences variables, it is the variable 'optimistic about the future' that is most strongly associated with individuals' preferences for redistributions. Adult sons who are optimistic about the future have a 13 percentage point lower likelihood of favoring redistribution. Moreover, those who think that what you achieve depends on luck are more likely to favor redistribution. These results are in line with the empirical findings in Alesina and LaFerrara (2005) and are also consistent with the prospect of upward mobility (POUM) hypothesis (Bénabou and Ok, 2001). The estimates for the second specification in Table 6 point to a considerable intergenerational association in preferences for redistribution. Sons 
whose father favors redistribution have an 18 percentage point higher likelihood of also preferring redistribution policies. Most importantly, the marginal effects on the various intergenerational transmission dummy variables are still precisely estimated and point to an important association between intergenerational mobility and preferences for redistribution.

\section{Sensitivity Analysis}

This section presents several alternative specifications to probe the robustness of the results. It is well known in the intergenerational mobility literature that the age of adult sons over which earnings are measured influences the intergenerational elasticity estimates (Grawe, 2006). In a first step, the age of sons at observation is therefore increased. Second, the above models for alternative measures of intergenerational mobility are estimated by using unemployment experience instead of earnings. Third, the robustness of the study's estimates is also examined while simultaneously conditioning on fathers' and sons' wealth (Pfeffer, 2011). Fourth, previous studies point to the importance of the proportion of welfare recipients and of immigrants in a community for individuals' preferences for redistribution (Luttmer, 2001; Dahlberg et al. 2012). In the light of these findings, the robustness of the study's estimates with respect to regional unemployment levels and the proportion of foreigners is investigated. The fifth sensitivity analysis controls for detailed economic expectations regarding adult sons' mobility, since there is growing empirical evidence that a positive relationship exists between individuals' mobility expectations and their attitudes towards redistribution (Alesina and La Ferrara, 2005; Rainer and Siedler, 2007). Finally, an alternative outcome measure is used eliciting individuals' preferences for redistribution through questions on the extent to which the government should be responsible for helping the unemployed (Alesina and FuchsSchündeln, 2002). Some results from these robustness checks are reported in the Appendix and others are available from the authors upon request.

Age restriction of adult children: A first robustness check comprised an examination of the sensitivity of the study's results to the age at which adult sons' earnings are measured. Table A1 reports the results when only adult sons aged 30 and above are included in the sample. As can be seen from the table, this change in the sample selection has little effect on the key results, but the sample size decreases considerably and some of the estimates lose statistical significance.

Alternative measure for social mobility: In alternative specifications, fathers' and

\footnotetext{
${ }^{9}$ Note, however, that the estimated coefficient in column 1 , Table 6 , is not precisely estimated.
} 
sons' unemployment experience was used as an alternative economic variable in order to measure intergenerational mobility. The study distinguished between three different groups for fathers and sons: (1) individuals with no unemployment experience; (2) individuals who report having been unemployed for 12 months or less and (3) individuals who report having been unemployed for more than 12 months during the panel years. Table A2 reports the intergenerational transition matrix for unemployment experience. The table shows, for example, that 59 percent of adult sons whose fathers were never unemployed do not report any unemployment experience. Table A3 reports the relationship between intergenerational transmission in unemployment experience and sons' preferences for redistribution. To measure the degree of intergenerational mobility, we generate 9 mutually exclusive dummy variables capturing all possible combinations in the extent of unemployment experience for fathers and sons. The reference category is father-son pairs who experienced unemployment for more than 12 months during the panel years. Consistent with the estimates in Table 5, the results in Table A3 point to a considerable relationship between intergenerational mobility and adult sons' preferences for redistribution, even though the marginal effects on downward mobility are not precisely estimated.

Wealth: One important result is that adult children at the top of the earnings distribution whose fathers' average earnings were also at the top of the distribution are less likely to display preferences for redistribution. This positive link might be partly driven by the fact that those from a higher earning background also come from richer families. Recent work by Pfeffer (2011) reports a distinct relationship between parents' wealth and children's educational outcomes, conditional on parents' household income. Table A4 displays the key coefficients, conditional on fathers' and sons' wealth. ${ }^{10}$ The majority of intergenerational estimates are robust to the inclusion of these additional control variables.

Expectations of future mobility - the POUM hypothesis: There is growing evidence that individuals' future expectations are strongly correlated to preferences for redistribution (Alesina and La Ferrara, 2005; Rainer and Siedler, 2007). Taken together, these empirical studies confirm the "Prospect of Upward Mobility (POUM) hypothesis" (Bénabou and Ok, 2001) that those with lower levels of income might not always oppose redistribution policies because they expect to be economically better off in the future. Thus, independent of

\footnotetext{
${ }^{10}$ In 2002, the SOEP included a battery of questions on individuals' wealth. "Do you possess the following types of property or wealth?" A. owner of the house/apartment in which you live?; B. possession of another house or more land?; C. financial assets over the value of 2500 Euro?; D. Life insurance or private pension plan?; E. owner of a commercial enterprise?; F. Assets over 2500 Euro in the form of gold, jewelry, coins or
} 
individuals' own and their fathers' economic mobility, those who have experienced upward mobility might be more likely to expect an improvement in their future earnings compared to those with less successful trajectories. Therefore, the link between intergenerational mobility and preferences for redistribution might not only capture past economic mobility, but also reflect differences in people's future expectations. To mitigate these concerns, in unreported regressions, various measures of subjective future expectations were also controlled for. For example, sons' self-assessed probability of getting a pay increase, losing their job, and being demoted in their company ${ }^{11}$ were all controlled for. The main estimates barely change when adult sons' future expectations are controlled for.

Regional characteristics: Luttmer (2001) reports that individuals' attitudes toward welfare spending decrease with an increasing proportion of benefit recipients in the community. The study by Dahlberg et al. (2012) reports a negative impact of increased immigration on the support for redistribution among natives. Table A5 reports the marginal effects on the various intergenerational mobility dummy variables when the proportion of immigrants and the unemployment rate at the regional (state) level is also controlled for. ${ }^{12}$ The results are again very similar to the ones presented in Table 5.

Alternative outcome: In the survey year 2002, the SOEP included alternative measures of individuals' preferences for redistribution. In particular, respondents were surveyed on the extent to which the government should be responsible for helping the unemployed (Alesina and Fuchs-Schündeln, 2007). The present model was estimated using a dichotomous outcome variable that is equal to one if adult sons answer that it should be "only" or "mainly" the responsibility of the state to provide a safety net in case of unemployment rather than the responsibility of private forces. ${ }^{13}$ Overall, 67 percent of adult sons answer that it should be the responsibility of the state rather than private forces to provide a safety net in case of unemployment. The intergenerational estimates for this alternative outcome measure were found to be consistent with the ones in Table 5. For example, adult sons who experienced long-term upward mobility from the very bottom to the

valuable collections?. Based on these answers, a summation index was generated over these dummy variables as a proxy for individuals' wealth, with a minimum possible value of zero and a maximum of six.

${ }^{11}$ These subjective future expectations are measured on an 11-point scale (from 0-100, rounding to the nearest 10 percent).

${ }^{12}$ The average unemployment rate (proportion of foreigners) at the state level in 2005 is 11.5 (8.9) percent.

${ }^{13}$ The survey question reads: „At present, a multitude of social services are provided not only by the state but also by private free market enterprises, organizations, associations, or private citizens. What is your opinion on this? Who should be responsible for the following areas?". Among the various areas we report the answers to the item "financial security in case of unemployment". Answers to the question can be given on a 5-point scale, which corresponds to 1 "only private forces", 2 "mostly private forces", 3 "state and private forces", 4 "mostly the state", 5 "only the state". 
top of the quartile have a 29 percentage point lower likelihood of opposing redistribution compared to those who stayed poor. Note, however, that these intergenerational estimates are based on a considerable smaller sample size than the ones in Table 5.

\section{Summary and Conclusions}

Piketty's (1995) theoretical model of redistributive politics assigns a key role to social background and economic mobility: Individuals who experience upward mobility are more likely to believe that effort is rewarded in society and are less likely to support redistribution policies. In contrast, individuals who have experienced downward mobility are less likely to think that effort is rewarded and are more likely to prefer redistribution taxation policies. To date, however, empirical evidence on this theory is sparse. The availability of rich household panel data with detailed information on long-term earnings for two generations, together with novel questions on individuals' preferences for redistribution have provided new opportunities to evaluate Piketty's rational-learning theory. Consistent with this theory, the present study shows that fathers' and sons' long-term earnings are significantly correlated with adult offspring's preferences for redistribution. Most importantly, the study's empirical results suggest that individuals who experience intergenerational upward (downward) mobility are less (more) likely to favor redistribution taxation policies. In addition, these relationships have been proven robust for the inclusion of several variables that were found to be important correlates in the previous empirical literature on individual preferences for redistribution such as altruism, risk attitudes, reciprocity, beliefs about the importance of selfdetermination for success later in life as well as individuals' expectation of future mobility.

There are several promising avenues for future research. The present study is the first to relate intergenerational mobility in long-term earnings to sons' preferences for redistribution. However, the present methodology cannot identify causal effects. This limitation mainly arises from the fact that there is no apparent exogenous variation for fathers and sons long-term earnings that could be exploited. One potential instrumental variable candidate for long-term earnings could be to use compulsory schooling reforms that are gradually introduced over time across regions as exogenous variation for individuals' longterm earnings. In Germany, compulsory schooling was gradually increased between 1949 and 1969 (Pischke and von Wachter, 2008; Siedler, 2010). These reforms might give plausible exogenous variation for the generation of fathers, but not for the generations of sons. Another promising strategy could be to generate predicted employment conditions at the regional level as exogenous variation for employment prospects, in the spirit of Brunner et al. (2011). A 
challenge for future research would, therefore, be to find convincing exogenous variation for both generations' earnings to estimate the causal impact of intergenerational mobility on preferences for redistribution. Second, it would be interesting to study the relationship between intergenerational long-term mobility and preferences for redistribution in other countries and to explore the importance of the educational system and labor market institutions for individuals' social mobility and support for the welfare state, for example. 


\section{References}

Alesina, A. and Giuliano, P. (2010), Preferences for redistribution, in Jess Benhabib, Matthew O. Jackson and Alberto Bisin (editors), Handbook of Social Economics, Vol. 1A, The Netherlands: North Holland, 93-131.

Alesina, A., Glaeser, E. and Sacerdote, B. (2001), Why doesn't the US have a European-style welfare state?, Brookings Papers on Economic Activity, 2001(2), 187-254.

Alesina, A. and La Ferrara, E. (2005), Preferences for redistribution in the land ofopportunities, Journal of Public Economics, 89(5-6), 897-931.

Alesina, A. and Fuchs-Schündeln (2007), Good-bye Lenin (or not?): The effect of communism on people's preferences, American Economic Review, 97(4): 1507-1528.

Bénabou, R. and Ok, E. A. (2001), Social mobility and the demand for redistribution. The POUM hypothesis, Quarterly Journal of Economics, 116(2), 447-487.

Bénabou, R. and Tirole, J. (2006), Belief in a just world and redistributive politics, Quarterly Journal of Economics, 121(2), 699-746.

Björklund, A. and Jäntti, M. (1997), Intergenerational income mobility in Sweden compared to the United States, American Economic Review, 87(4), 1009-18.

Black, S. E. and Devereux, P. J. (2011), Recent developments in intergenerational mobility. Handbook of Labor Economics, vol. 4b, part 2, 1487-1541.

Bowles, S. and Gintis, H. (2002), The inheritance of inequality, Journal of Economic Perspectives, 16(3), 3-30.

Brunner, E., Ross, S. L. and Washington, E. (2011), Economics and Policy Preferences: Causal Evidence of the Impact of Economic Conditions on Support for Redistribution and other Ballot Proposals, Review of Economics and Statistics, 93(3), 888-906.

Corak, M. and Heisz, A. (2003), The intergenerational earnings and income mobility of Canadian men: Evidence from longitudinal income tax data, Journal of Human Resources, 34(3), 504-533.

Corak, M., ed. (2004), Generational Income Mobility in North America and Europe. Cambridge University Press: Cambridge.

Corneo, G. and Grüner H. P. (2002), Individual preferences for political redistribution, Journal of Public Economics, 83(1), 83-107.

Couch, K. A. and Dunn, T. A. (1997), Intergenerational correlations in labor market status: A comparison of the United States and Germany, Journal of Human Resources, 32(1), 210232.

Dahlberg, M., Edmark, K. and Lundqvist, H. (2012), Ethnic diversity and preferences for redistribution, Journal of Political Economy, 120(1), 41-76. 
Dearden, L., Machin, S. and Reed, H. (1997), Intergenerational mobility in Britain, Economic Journal, 107, 47-66.

Di Tella, R., Galiani, S. and Schargrodsky, E. (2007), The formation of beliefs: Evidence from the allocation of land titles to squatters, Quarterly Journal of Economics, 122(1), 209241.

Dohmen, T., Falk, A., Huffman, D., Sunde, U., Schupp, J. and Wagner, G. G. (2011), Individual Risk Attitudes: Measurement, Determinants and Behavioral Consequences, Journal of the European Economic Association, 9(3): 522-550.

Fong, C. (2001), Social preferences, self-interest, and the demand for redistribution, Journal of Public Economics, 82(2), 225-246.

Fong, C., Bowles, S. and Gintis, H. (2005), Behavioural motives for income redistribution, Australian Economic Review, 38(3), 285-97.

Grawe, N. D. (2006), Lifecycle bias in estimates of intergenerational earnings persistence, Labour Economics, 13(5), 551-570.

Giuliano, P. and Spilimbergo, A. (2009), Growing up in a recession: beliefs and the macroeconomy. IZA discussion paper no. 4365, Bonn.

Holmlund, H., Lindahl, M. and Plug, E. (2011), The causal effect of parents' schooling on children's schooling: a comparison of estimation methods, Journal of Economic Literature, 49(3), 615-651.

Jäntti, M., Bratsberg, B., Roed, K., Raaum, O., Nayloer, R., Osterbacka, E., Björklund, A. and Eriksson, T. (2006), American Exceptionalism in a New Light: A Comparison of Intergenerational Earnings Mobility in the Nordic Countries, the United Kingdom and the United States, IZA Discussion Paper 1938, Bonn.

Klor, E. F. and Shayo, M. (2010), Social identity and preferences over redistribution. Journal of Public Economics, 94

Kroh, M. and Selb, P. (2009), Inheritance and the Dynamics of Party Identification, Political Behavior, 31, 559-574.

Luttmer, E. F. (2001), Group loyalty and the taste for redistribution, Journal of Political Economy, 109(3), 500-528.

Nicoletti, C. and Ermisch, J. (2007), Intergenerational earnings mobility: changes across cohorts in Britain, The B.E. Journal of Economic Analysis \& Policy, 7(2), 1-37.

OECD (2011), Taxing Wages 2010, OECD Publishing.

Peters, E. (1988), Retrospective versus panel data in analyzing lifecycle events, Journal of Human Resources, 24(4), 488-513. 
Pfeffer, F. (2011), Status attainment and wealth in the United States and Germany. In: Persistence, Privilege, and Parenting, edited by Timothy M. Smeeding, Robert Erikson, and Markus Jäntti, 109-137. New York: Russell Sage Foundation.

Piketty, T. (1995), Social mobility and redistributive politics, Quarterly Journal of Economics, 110(3), 551-584.

Pischke, J.-S. and von Wachter, T. (2008), Zero returns to compulsory schooling in Germany: evidence and interpretation. Review of Economics and Statistics, 90(3), 592-598.

Rainer, H. and Siedler, T. (2008), Subjective income and employment expectations and preferences for redistribution, Economics Letters, 99(3), 449-453.

Ravallion, M. Lokshin, M. (2000), Who wants to redistribute? The tunnel effect in 1990s Russia, Journal of Public Economics, 76(1), 87-104.

Rubin, D. C. (1996), Remembering our past. Studies in Autobiographical Memory, Cambridge, Cambridge University Press.

Senik, C., Stichnoth, H. and K. Van der Straeten (2009), Immigration and natives' attitudes towards the welfare state: evidence from the European Social Survey." Social Indicators Research, 91, 345-70.

Siedler, T. (2010), Schooling and citizenship in a young democracy: evidence from post-war Germany. Scandinavian Journal of Economics, 112(2), 315-338.

Solon, G. R. (1992), Intergenerational income mobility in the United States, American Economic Review, 82(3), 393-408.

Solon, G. R. (2002), Cross-country differences in intergenerational earnings mobility, Journal of Economic Perspectives, 16(3), 59-66.

Stichnoth, H. (2010), Does immigration weaken natives' support for the welfare state? Evidence from Germany, ZEW Discussion Paper No. 10-008, Mannheim.

Stichnoth, H., and K. Van der Straeten (forthcoming), Ethnic diversity, public spending, and individual support for the welfare state: A review of the empirical literature. Journal of Economic Surveys.

Wagner, G. G., Frick, J. R. and Schupp, J. (2007), The German Socio-Economic Panel Study (SOEP) - Scope, Evolution and Enhancements, Schmollers Jahrbuch, 127(1), 139-169.

Zimmerman, D. J. (1992), Regression toward Mediocrity in Economic Stature, American Economic Review, 82(3), 409-429.

Zuckerman, A. S. and Kroh, M. (2006), The Social Logic of Bounded Partisanship in Germany: A Comparison of West Germans, East Germans, and Immigrants, Comparative European Politics, 4, 65-93. 


\section{Figures and Tables:}

Figure 1: Preferences for Redistribution, Adult Sons

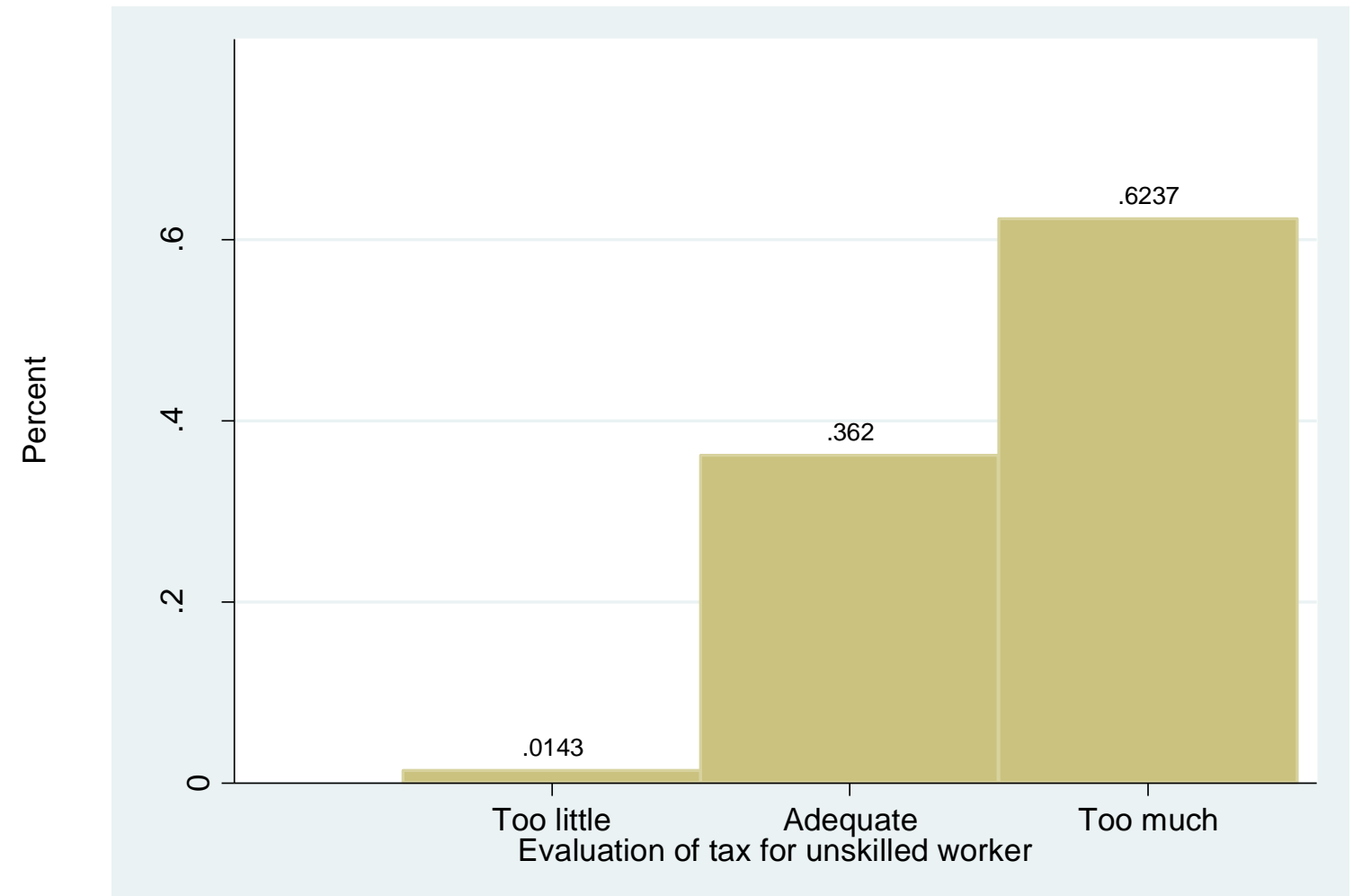

Notes: The sample includes 837 adult sons. The histogram shows the distributions of responses to the question on the amount of tax paid by an unskilled worker in Germany. 
Table 1: Quartile Transition Matrix for Long-term Earnings of 837 Fathers and Sons

\begin{tabular}{|c|c|c|c|c|}
\hline $\begin{array}{l}\text { Sons' earnings } \\
\text { Fathers' earnings }\end{array}$ & Bottom & Second & Third & Top \\
\hline \multirow[t]{2}{*}{ Bottom } & 31.43 & 27.62 & 25.71 & 15.24 \\
\hline & 66 & 58 & 54 & 32 \\
\hline \multirow[t]{2}{*}{ Second } & 20.10 & 29.19 & 31.10 & 19.62 \\
\hline & 42 & 61 & 65 & 41 \\
\hline \multirow[t]{2}{*}{ Third } & 18.66 & 23.92 & 27.75 & 29.67 \\
\hline & 39 & 50 & 58 & 62 \\
\hline \multirow[t]{2}{*}{ Top } & 30.14 & 19.14 & 15.31 & 35.41 \\
\hline & 63 & 40 & 32 & 74 \\
\hline Number of observations & 210 & 209 & 209 & 209 \\
\hline
\end{tabular}

Table 2: Proportion of Sons in Favor of Redistribution (Evaluation of Tax paid by Unskilled Workers), by Intergenerational Transition Matrix

Panel A

\begin{tabular}{cllll}
\hline $\begin{array}{l}\text { Sons' earnings } \\
\text { Fathers' earnings }\end{array}$ & Bottom & Second & Third & Top \\
\hline Bottom & 80.30 & 79.31 & 68.52 & 53.13 \\
& 66 & 58 & 54 & 32 \\
Second & 73.81 & 60.66 & 66.15 & 58.54 \\
& 42 & 61 & 65 & 41 \\
Third & 71.79 & 64.00 & 58.62 & 48.39 \\
& 39 & 50 & 58 & 62 \\
Top & 61.90 & 65.00 & 53.13 & 37.84 \\
& 63 & 40 & 32 & 74 \\
\hline
\end{tabular}

Notes: SOEP 1984-2006. Table displays proportion of sons indicating that taxes for unskilled workers are too high (in contrast to too little or adequate taxing).

\section{Panel B}

\begin{tabular}{lll}
\hline Sons' earnings & $\begin{array}{l}\text { Below the } \\
\text { Median }\end{array}$ & $\begin{array}{l}\text { Above the } \\
\text { median }\end{array}$ \\
Fathers' earnings & 73.57 & 63.02 \\
\hline Below the median & 227 & 192 \\
Above the median & 65.10 & 48.23 \\
& 192 & 226 \\
\hline
\end{tabular}

Notes: SOEP 1984-2006. Table displays proportion of sons indicating that taxes for unskilled workers are too high (in contrast to too little or adequate taxing). 
Table 3: Summary Statistics of Explanatory Variables

\begin{tabular}{|c|c|c|c|c|}
\hline \multirow[b]{2}{*}{ Variable } & \multicolumn{2}{|c|}{ Sons } & \multicolumn{2}{|c|}{ Fathers } \\
\hline & Mean & Std. Dev. & Mean & Std. Dev. \\
\hline Age & 33.04 & 6.72 & 61.79 & 8.36 \\
\hline East German & 0.17 & & & \\
\hline Guestworker & 0.19 & & & \\
\hline \multicolumn{5}{|l|}{ Average earnings, by quartiles } \\
\hline Average earnings overall & 30792 & 19241 & 34164 & 21699 \\
\hline Bottom quartile & 10458 & 5171 & 16941 & 4636 \\
\hline Second quartile & 23926 & 3063 & 25998 & 1811 \\
\hline Third quartile & 33389 & 2909 & 33217 & 3077 \\
\hline Top quartile & 55494 & 18938 & 60584 & 28096 \\
\hline \multicolumn{5}{|l|}{ Highest educational qualification } \\
\hline Less than high school & 0.11 & & 0.14 & \\
\hline High school & 0.67 & & 0.65 & \\
\hline More than high school & 0.22 & & 0.22 & \\
\hline \multicolumn{5}{|c|}{ Household composition and marital status } \\
\hline Married & 0.39 & & & \\
\hline Number of adults in household & 2.89 & & & \\
\hline Number of children in household & 0.64 & & & \\
\hline Number of observations ${ }^{+}$ & & 837 & & \\
\hline \multicolumn{5}{|c|}{ Risk aversion, beliefs of social mobility and optimism } \\
\hline Person takes no overall risks & 0.47 & & 0.69 & \\
\hline Life course depends on me & 0.85 & & 0.75 & \\
\hline Achievements depend on luck & 0.27 & & 0.34 & \\
\hline Very or important to help others & 0.21 & & 0.16 & \\
\hline Optimistic towards future & 0.80 & & 0.61 & \\
\hline Preferences for redistribution & 0.62 & & 0.64 & \\
\hline Number of observations ${ }^{++}$ & & 601 & & \\
\hline
\end{tabular}

Notes: Figures shown are sample means and standard deviations. The summary statistics are reported for the year 2005 , except of risk attitudes which are reported in the year 2004. ${ }^{+}$Except of the average earnings by quartiles and for father's highest school degree (sample size: 631). ${ }^{++}$Except of father's preferences for redistribution (sample size: 466). 
Table 4: Fathers' and Sons' Average Earnings and Sons' Preferences for Redistribution

\begin{tabular}{lcc}
\hline & $\begin{array}{c}\text { Marginal } \\
\text { Effects }\end{array}$ & $\begin{array}{c}\text { Standard } \\
\text { Errors }\end{array}$ \\
\hline Age & -0.003 & $(0.029)$ \\
Age squared & 0.001 & $(0.000)$ \\
East German & $-0.103^{*}$ & $(0.054)$ \\
Guestworker & 0.006 & $(0.049)$ \\
Currently married & -0.067 & $(0.052)$ \\
Number of persons in the household & 0.001 & $(0.020)$ \\
Number of kids in the household & 0.044 & $(0.034)$ \\
High school education & -0.024 & $(0.059)$ \\
More than high school & $-0.142^{*}$ & $(0.077)$ \\
Log average long-term earnings & $-0.084^{* * *}$ & $(0.030)$ \\
Log father's longer-term earnings & $-0.110^{* * *}$ & $(0.041)$ \\
Observations & & 837 \\
Pseudo $R^{2}$
\end{tabular}

Notes: Marginal effects from a probit model, with standard errors in parentheses. The dependent variable equals one if a respondent says that taxes paid by unskilled workers are too high, and zero otherwise. The model also control for occupational dummy variables for adult sons (five categories) and for father's age and age-squared. Robust standard errors, clustered at father's identification number, in parentheses. * significant at 10\%; ** significant at 5\%; *** significant at $1 \%$ level. 
Table 5: Preferences for Redistribution by Father-Son Earnings Quartiles

Panel A

\begin{tabular}{|c|c|c|c|c|}
\hline Sons' Earnings & Bottom & Second & Third & Top \\
\hline \multicolumn{5}{|l|}{ Fathers' Earnings } \\
\hline Bottom & & $\begin{array}{c}-0.054 \\
(0.106)\end{array}$ & $\begin{array}{l}-0.242^{* *} \\
(0.106)\end{array}$ & $\begin{array}{c}-0.314^{* * * *} \\
(0.109)\end{array}$ \\
\hline Second & $\begin{array}{l}-0.093 \\
(0.112)\end{array}$ & $\begin{array}{c}-0.327^{* * * *} \\
(0.096)\end{array}$ & $\begin{array}{c}-0.279^{* * * *} \\
(0.101)\end{array}$ & $\begin{array}{c}-0.280^{* *} \\
(0.144)\end{array}$ \\
\hline Third & $\begin{array}{c}-0.102 \\
(0.108)\end{array}$ & $\begin{array}{c}-0.273^{* * * *} \\
(0.103)\end{array}$ & $\begin{array}{c}-0.327^{* * * *} \\
(0.095)\end{array}$ & $\begin{array}{c}-0.349^{* * * *} \\
(0.095)\end{array}$ \\
\hline Top & $\begin{array}{c}-0.227^{* *} \\
(0.104)\end{array}$ & $\begin{array}{l}-0.187^{*} \\
(0.112)\end{array}$ & $\begin{array}{c}-0.312^{* * * *} \\
(0.108)\end{array}$ & $\begin{array}{c}-0.437^{* * * *} \\
(0.088)\end{array}$ \\
\hline Number of observations & \multicolumn{4}{|c|}{837} \\
\hline \multicolumn{5}{|c|}{$\begin{array}{l}\text { Notes: Marginal effects from a probit model, with standard errors in parentheses. The } \\
\text { dependent variable equals one if a respondent says that taxes paid by unskilled workers are } \\
\text { too high, and zero otherwise. The model also controls for age, age }{ }^{2} \text {, East German, } \\
\text { guestworker, currently married, number of persons/children in the household, occupational } \\
\text { status (five categories), education (three categories), fathers' age and age }{ }^{2} \text {. Robust standard } \\
\text { errors, clustered at father's identification number, in parentheses. * significant at } 10 \% \text {; ** } \\
\text { significant at 5\%; *** significant at } 1 \% \text { level. }\end{array}$} \\
\hline
\end{tabular}


Table 6: Intergenerational Mobility, Preferences and Attitudes

\begin{tabular}{|c|c|c|c|c|}
\hline \multirow[t]{2}{*}{ Outcome variable: } & \multicolumn{4}{|c|}{$\begin{array}{l}\text { Evaluation of tax paid } \\
\text { by unskilled workers }\end{array}$} \\
\hline & $\begin{array}{l}\text { Marginal } \\
\text { Effects }\end{array}$ & $\begin{array}{c}\text { Standard } \\
\text { errors }\end{array}$ & $\begin{array}{c}\text { Marginal } \\
\text { Effects }\end{array}$ & $\begin{array}{l}\text { Standard } \\
\text { Errors }\end{array}$ \\
\hline \multicolumn{5}{|l|}{ Fathers' Quartile - Sons' Quartile } \\
\hline Bottom - Second & -0.204 & $(0.137)$ & $-0.321^{*}$ & $(0.163)$ \\
\hline Bottom - Third & $-0.429^{* * *}$ & $(0.115)$ & $-0.516^{* * *}$ & $(0.123)$ \\
\hline Bottom - Top & $-0.342^{* *}$ & $(0.152)$ & $-0.407^{*}$ & $(0.198)$ \\
\hline Second - Bottom & -0.177 & $(0.130)$ & $-0.327^{* *}$ & $(0.150)$ \\
\hline Second - Second & $-0.443^{* * *}$ & $(0.105)$ & $-0.532^{* * *}$ & $(0.109)$ \\
\hline Second - Third & $-0.279^{* *}$ & $(0.129)$ & $-0.482^{* * *}$ & $(0.129)$ \\
\hline Second - Top & $-0.375^{* *}$ & $(0.141)$ & -0.369 & $(0.216)$ \\
\hline Third - Bottom & -0.127 & $(0.134)$ & -0.169 & $(0.167)$ \\
\hline Third - Second & $-0.341^{* * * *}$ & $(0.119)$ & $-0.448^{* * *}$ & $(0.131)$ \\
\hline Third - Third & $-0.380^{* * *}$ & $(0.114)$ & $-0.498^{* * *}$ & $(0.122)$ \\
\hline Third - Top & $-0.407^{* * *}$ & $(0.113)$ & $-0.421^{* * *}$ & $(0.138)$ \\
\hline Top - Bottom & $-0.270^{* *}$ & $(0.124)$ & $-0.341^{* *}$ & $(0.143)$ \\
\hline Top - Second & -0.173 & $(0.140)$ & -0.224 & $(0.165)$ \\
\hline Top - Third & $-0.369^{* * *}$ & $(0.122)$ & $-0.470^{* * *}$ & $(0.128)$ \\
\hline Top - Top & $-0.514^{* * *}$ & $(0.094)$ & $-0.615^{* * *}$ & $(0.090)$ \\
\hline Life course depends on me & $-0.129^{* *}$ & $(0.056)$ & -0.108 & $(0.065)$ \\
\hline What you achieve depends on luck & $0.126^{* * *}$ & $(0.046)$ & $0.103^{*}$ & $(0.054)$ \\
\hline Person takes no overall risk & $-0.077^{*}$ & $(0.045)$ & $-0.106^{*}$ & $(0.055)$ \\
\hline Very or important to help others & 0.056 & $(0.055)$ & 0.081 & $(0.059)$ \\
\hline Optimistic towards future & $-0.129^{* *}$ & $(0.052)$ & $-0.128^{* *}$ & $(0.060)$ \\
\hline \multicolumn{5}{|l|}{ Fathers } \\
\hline Life course depends on me & -0.048 & $(0.050)$ & -0.035 & $(0.060)$ \\
\hline What you achieve depends on luck & 0.076 & $(0.047)$ & 0.081 & $(0.054)$ \\
\hline Person takes no overall risk & 0.081 & $(0.052)$ & $0.123^{* *}$ & $(0.062)$ \\
\hline Very or important to help others & -0.023 & $(0.060)$ & -0.087 & $(0.072)$ \\
\hline Optimistic towards future & -0.026 & $(0.046)$ & -0.032 & $(0.057)$ \\
\hline Fathers' preferences for redistribution & & & $0.187^{* * *}$ & $(0.050)$ \\
\hline Observations & \multicolumn{2}{|c|}{601} & \multicolumn{2}{|c|}{459} \\
\hline Pseudo R-squared & \multicolumn{2}{|c|}{0.158} & \multicolumn{2}{|c|}{0.231} \\
\hline
\end{tabular}




\section{Appendix}

Table A1: Preferences for Redistribution by Father-Son Earnings Quartiles (Sons aged 30+)

\begin{tabular}{|c|c|c|c|c|}
\hline Sons' Earnings & Bottom & Second & Third & Top \\
\hline \multicolumn{5}{|l|}{ Fathers' Earnings } \\
\hline Bottom & & $\begin{array}{c}-0.132 \\
(0.168)\end{array}$ & $\begin{array}{l}-0.315^{*} \\
(0.151)\end{array}$ & $\begin{array}{c}-0.348^{* *} \\
(0.150)\end{array}$ \\
\hline Second & $\begin{array}{c}-0.394^{* * *} \\
(0.158)\end{array}$ & $\begin{array}{c}-0.392^{* * *} \\
(0.135)\end{array}$ & $\begin{array}{c}-0.367^{* *} \\
(0.140)\end{array}$ & $\begin{array}{l}-0.312^{*} \\
(0.162)\end{array}$ \\
\hline Third & $\begin{array}{l}-0.141 \\
(0.200)\end{array}$ & $\begin{array}{c}-0.479^{* * * *} \\
(0.113)\end{array}$ & $\begin{array}{c}-0.388^{* * *} \\
(0.139)\end{array}$ & $\begin{array}{c}-0.373^{* * *} \\
(0.141)\end{array}$ \\
\hline Top & $\begin{array}{c}0.045 \\
(0.196)\end{array}$ & $\begin{array}{l}-0.253 \\
(0.177)\end{array}$ & $\begin{array}{l}-0.352^{*} \\
(0.164)\end{array}$ & $\begin{array}{c}-0.433^{\text {**** }} \\
(0.137)\end{array}$ \\
\hline Number of observations & \multicolumn{4}{|c|}{546} \\
\hline Pseudo R-squared & \multicolumn{4}{|c|}{0.127} \\
\hline
\end{tabular}

Notes: Marginal effects from a probit model, with standard errors in parentheses. The dependent variable equals one if adult sons say that taxes paid by unskilled workers are too high, and zero otherwise. The model also controls for age, age ${ }^{2}$, East German, guestworker, currently married, number of persons/children in the household, occupational status (five categories), education (three categories), fathers' age and age ${ }^{2}$. Robust standard errors, clustered at father's identification number, in parentheses. * significant at 10\%; ** significant at $5 \%$; *** significant at $1 \%$ level. 
Table A2: Transition Matrix for Unemployment Experience of Fathers and Sons

\begin{tabular}{lccc}
\hline Sons' unemployment & $\begin{array}{c}\text { More than } \\
12 \text { months }\end{array}$ & $\begin{array}{c}12 \text { months } \\
\text { or less }\end{array}$ & $\begin{array}{c}\text { No } \\
\text { unemployment }\end{array}$ \\
\hline Fathers' unemployment & & & \\
More than 12 months & 24.49 & 33.16 & 42.35 \\
& 48 & 65 & 83 \\
12 months or less & 25.58 & 26.74 & 47.67 \\
& 22 & 23 & 41 \\
No unemployment & 10.92 & 30.25 & 58.82 \\
& 39 & 108 & 210 \\
\hline
\end{tabular}

Table A3: Preferences for Redistribution by Father-Son Unemployment Experience

\begin{tabular}{|c|c|c|c|}
\hline Sons' Unemployment & $\begin{array}{l}\text { More than } 12 \\
\text { months }\end{array}$ & $\begin{array}{l}12 \text { months } \\
\text { or less }\end{array}$ & $\begin{array}{c}\text { No } \\
\text { unemployment }\end{array}$ \\
\hline \multicolumn{4}{|l|}{ Fathers' Unemployment } \\
\hline More than 12 months & & $\begin{array}{l}-0.180^{*} \\
(0.111)\end{array}$ & $\begin{array}{l}-0.264^{* *} \\
(0.105)\end{array}$ \\
\hline 12 months or less & $\begin{array}{c}0.056 \\
(0.135)\end{array}$ & $\begin{array}{l}-0.272^{*} \\
(0.137)\end{array}$ & $\begin{array}{c}-0.309^{* * *} \\
(0.113)\end{array}$ \\
\hline No unemployment & $\begin{array}{l}-0.069 \\
(0.121)\end{array}$ & $\begin{array}{c}-0.262^{* * *} \\
(0.100)\end{array}$ & $\begin{array}{c}-0.275^{\text {**** }} \\
(0.095)\end{array}$ \\
\hline Number of observations & & 631 & \\
\hline Pseudo R-squared & & 0.094 & \\
\hline \multicolumn{4}{|c|}{$\begin{array}{l}\text { Notes: Marginal effects from a probit model, with standard errors in parentheses. The dependent variable } \\
\text { equals one if adult sons say that taxes paid by unskilled workers are too high, and zero otherwise. The } \\
\text { model also controls for age, age }{ }^{2} \text {, East German, guestworker, currently married, number of } \\
\text { persons/children in the household, occupational status (five categories), education (three categories), } \\
\text { fathers' age and age }{ }^{2} \text {. Robust standard errors, clustered at father's identification number, in parentheses. * } \\
\text { significant at } 10 \% \text {; ** significant at 5\%; *** significant at } 1 \% \text { level. }\end{array}$} \\
\hline
\end{tabular}


Table A4: Preferences for Redistribution by Father-Son Earnings Quartiles (Controlling for fathers' and sons' wealth)

\begin{tabular}{lllll}
\hline Sons' Earnings & Bottom & Second & Third & Top \\
\hline Fathers' Earnings & & & & \\
Bottom & & -0.074 & $-0.277^{* *}$ & -0.197 \\
& & $(0.123)$ & $(0.125)$ & $(0.152)$ \\
Second & -0.121 & $-0.405^{* * *}$ & $-0.224^{*}$ & $-0.405^{* *}$ \\
& $(0.123)$ & $(0.097)$ & $(0.118)$ & $(0.097)$ \\
Third & -0.066 & $-0.266^{* *}$ & $-0.327^{* * *}$ & $-0.324^{* * *}$ \\
& $(0.123)$ & $(0.115)$ & $(0.104)$ & $(0.112)$ \\
Top & $-0.213^{*}$ & $-0.228^{*}$ & $-0.351^{* * *}$ & $-0.412^{* * *}$ \\
& $(0.115)$ & $(0.123)$ & $(0.114)$ & $(0.104)$ \\
Number of observations & \multicolumn{3}{c}{667} \\
Pseudo R-squared & \multicolumn{5}{c}{0.10} \\
\hline
\end{tabular}

Notes: Marginal effects from a probit model, with standard errors in parentheses. The dependent variable equals one if adult sons say that taxes paid by unskilled workers are too high, and zero otherwise. The model also controls for age, age ${ }^{2}$, East German, guestworker, currently married, number of persons/children in the household, occupational status (five categories), education (three categories), fathers' age and age ${ }^{2}$. Robust standard errors, clustered at father's identification number, in parentheses. * significant at 10\%; ** significant at 5\%; *** significant at $1 \%$ level.

Table A5: Preferences for Redistribution by Father-Son Earnings Quartiles (Controlling for state unemployment rate and proportion of foreigners in 2006)

\begin{tabular}{lcccc}
\hline Sons' Earnings & Bottom & Second & Third & Top \\
\hline Fathers' Earnings & & & & \\
Bottom & & -0.033 & $-0.240^{* *}$ & $-0.289^{* *}$ \\
& & $(0.104)$ & $(0.108)$ & $(0.115)$ \\
Second & -0.106 & $-0.312^{* * *}$ & $-0.236^{* *}$ & $-0.263^{* *}$ \\
& $(0.119)$ & $(0.010)$ & $(0.108)$ & $(0.118)$ \\
Third & -0.038 & $-0.251^{* *}$ & $-0.304^{* * *}$ & $-0.305^{* * *}$ \\
& $(0.112)$ & $(0.107)$ & $(0.099)$ & $(0.100)$ \\
Top & $-0.236^{* *}$ & -0.167 & $-0.296^{* *}$ & $-0.414^{* * *}$ \\
& $(0.106)$ & $(0.112)$ & $(0.111)$ & $(0.094)$ \\
Number of observations & \multicolumn{5}{c}{827} \\
Pseudo R-squared
\end{tabular}

Notes: Marginal effects from a probit model, with standard errors in parentheses. The dependent variable equals one if adult sons say that taxes paid by unskilled workers are too high, and zero otherwise. The model also controls for age, age ${ }^{2}$, East German, guestworker, currently married, number of persons/children in the household, occupational status (five categories), education (three categories), fathers' age and age ${ }^{2}$. Robust standard errors, clustered at father's identification number, in parentheses. * significant at $10 \%$; ** significant at $5 \%$; *** significant at $1 \%$ level. 
Table A6: Alternative Outcome Measure

(Dependent variable: State should be responsible for financial security when unemployed)

\begin{tabular}{|c|c|c|c|c|}
\hline Sons' Earnings & Bottom & Second & Third & Top \\
\hline \multicolumn{5}{|l|}{ Fathers' Earnings } \\
\hline Bottom & & $\begin{array}{c}-0.173 \\
(0.127)\end{array}$ & $\begin{array}{l}-0.174 \\
(0.140)\end{array}$ & $\begin{array}{c}-0.283^{* *} \\
(0.138)\end{array}$ \\
\hline Second & $\begin{array}{l}-0.169 \\
(0.145)\end{array}$ & $\begin{array}{c}-0.135^{* * * *} \\
(0.123)\end{array}$ & $\begin{array}{l}-0.213^{*} \\
(0.126)\end{array}$ & $\begin{array}{c}-0.277^{* *} \\
(0.137)\end{array}$ \\
\hline Third & $\begin{array}{c}-0.178 \\
(0.140)\end{array}$ & $\begin{array}{l}-0.238^{*} \\
(0.130)\end{array}$ & $\begin{array}{l}-0.131 \\
(0.126)\end{array}$ & $\begin{array}{c}-0.297^{* *} \\
(0.125)\end{array}$ \\
\hline Top & $\begin{array}{l}-0.164 \\
(0.136)\end{array}$ & $\begin{array}{c}-0.320^{* *} \\
(0.136)\end{array}$ & $\begin{array}{l}-0.225^{*} \\
(0.136)\end{array}$ & $\begin{array}{c}-0.272^{* *} \\
(0.133)\end{array}$ \\
\hline Number of observations & \multicolumn{4}{|c|}{649} \\
\hline Pseudo R-squared & \multicolumn{4}{|c|}{0.185} \\
\hline \multicolumn{5}{|c|}{$\begin{array}{l}\text { Notes: Marginal effects from a probit model, with standard errors in parentheses. The } \\
\text { dependent variable equals one if adult sons say that it should be "only the state" or } \\
\text { "mostly the state" to the survey question on who should be responsible for the financial } \\
\text { security in case of unemployment, and zero otherwise. The model also controls for age, } \\
\text { age } \text {, East German, guestworker, currently married, number of persons/children in the } \\
\text { household, occupational status (five categories), education (three categories), fathers' age } \\
\text { and age } 2 \text { Robust standard errors, clustered at father's identification number, in } \\
\text { parentheses. * significant at 10\%; ** significant at 5\%; *** significant at } 1 \% \text { level. }\end{array}$} \\
\hline
\end{tabular}

